\title{
Analysis of Factors Associated with Compliance with Taking Medicines for Pulmonary Tuberculosis Patients at Lut Tawar Health Center, Central Aceh Regency
}

\author{
Mappeaty Nyorong ${ }^{1}$, Thomson P. Nadapdap ${ }^{1}$, Linda Yanthy ${ }^{2}$ \\ ${ }^{1}$ Lecturer of Master of Public Health, Helvetia Institute of Health, Indonesia \\ ${ }^{2}$ Student of Master of Public Health Study Program, Helvetia Institute of Health, Indonesia \\ Received: November 15, 2021 \\ Received in Revised: December 14, \\ Accepted: December 25, 2021 \\ 2021
}

\begin{abstract}
There is a worldwide epidemic of tuberculosis (TB). As of May 31st, 2021, the Lut Tawar Health Center had recorded 10 instances in 2019, and 17 cases had been recorded as of that date. The purpose of this research is to evaluate the analysis of variables influencing medication adherence in pulmonary TB patients at the Lut Tawar Health Center, Lut Tawar District, Central Aceh Regency. Research is conducted using a cross-sectional design using quantitative analytic techniques. As many as 33 tuberculosis patients are enrolled in the Lut Tawar Health Center's TB treatment program. Total sampling was employed as the sampling strategy. Univariate, bivariate and multivariate analyses were used to analyze the data. There were no statistically significant differences in the p-values for education (0.000), employment (0.000), distance from home (0.000), knowledge (0.00), medication side effects (0.024), or family support (0.024) in the chi square analysis. Multivariate analysis indicated that the pharmacological side effect variable had a value $(\mathrm{p}=0.000)$ that was the most significant. Patients and families should be supported by the puskesmas, or health professionals, in charge of running the TB treatment program, so that they can keep tabs on their loved ones' medication compliance and avoid drug withdrawal and resistance. As part of the health education provided by health professionals, they describe the side effects of TB medications and encourage patients to continue taking them until they are well enough to do so.
\end{abstract}

Keywords: Compliance, Education, Occupation, Distance from Residence, Knowledge, Drug Side Effects, Family Support

\section{Introduction}

Pulmonary tuberculosis is a significant public health concern in Indonesia, resulting in high rates of morbidity and death. The bacteria Mycobacterium tuberculosis causes pulmonary tuberculosis, a persistent infectious illness. The germs that cause pulmonary tuberculosis are spread mostly by droplets generated by patients while sneezing or even speaking. According to Makhfudli, (2016) Tuberculosis (TB) is a significant public health concern worldwide; there were 10.0 million TB incident cases worldwide in 2017, including 5.8 million men, 3.2 million women, and 1.0 million children. There were instances in all nations and age categories, although $90 \%$ of cases were adults (aged 15 years), accounting for 9\% of HIV-positive individuals. Southeast Asia (44 percent) and the Western Pacific (44 percent) had the largest number of cases (18 percent ). There are eight nations with the largest number of tuberculosis cases, accounting for two-thirds of all worldwide tuberculosis cases: India (26\%), Indonesia $(8.5 \%)$, China $(8.4 \%)$, the Philippines (6\%), Pakistan $(5.7 \%)$, Nigeria (4.4\%), Bangladesh (3.6\%), and South Africa (3.6\%). (3.6 percent ). The World Health Organization classifies nations as having a high burden of tuberculosis (TB) based on three indicators: TB, TB/HIV, and MDR-TBC (WHO, 2018). The list includes 48 nations. One nation may be on one of these 
lists, or both may appear on all three. Indonesia is one of the 14 nations on the HBC list, which covers the three indicators that have the most difficulty dealing with tuberculosis patients. (3) According to WHO (2017) health profile data, the number of pulmonary tuberculosis patients was 360,565 in 2016, with a prevalence of 139 per 100,000 Indonesian population, and increased to 425,089 in 2017, with a prevalence of 162/100,000 Indonesian population. The success rate for pulmonary tuberculosis therapy is 85.7 percent, falling short of the WHO aim of at least 90 percent (Kemenkes, 2017).

According to data from the Central Aceh District Health Office, 912 cases of tuberculosis were discovered in 2017, with a cure rate of 19.3 percent, DO 1.2 percent, MDR 2.3 percent, and 0 percent deaths; 894 cases were discovered in 2018, with a cure rate of 39.1 percent, DO 0.5 percent, MDR 2.3 percent, and 0 percent deaths; 761 cases were discovered in 2019, with a cure rate of 22.9 percent, DO 0 percent, MDR And at the Lut Tawar Health Center itself, in 2019 there were ten cases with a cure rate of $70 \%$, ten DO cases, ten MDR cases, and ten deaths, while in 2020 there were twenty-three cases with a cure rate of $47 \%$, ten DO cases, ten MDR cases, and ten deaths. As of May 31, 2021, 17 instances have been discovered. The cure rate for pulmonary tuberculosis is calculated as the proportion of patients who finish therapy, while the treatment success rate is calculated as the cure rate plus the percentage of patients who complete treatment. The government has set a goal of 90 percent treatment success rate (success rate). The poor rate of cure coverage and effective treatment of pulmonary tuberculosis is a severe concern that deteriorates public health status. There are several factors contributing to the high number of tuberculosis cases in Indonesia, including the fact that pulmonary tuberculosis disease is difficult to treat due to patients' inability to adhere to routine treatment for 6-8 months until they finally discontinue treatment (DO) because they believe they have recovered. Additionally, TB problems are exacerbated by the increasing number of HIV/AIDS infections. rapid and the issue of MDR-TB (Multi Drug Resistant or Immune to Various Drugs), in addition to the fact that poor body resistance is a factor of TB illness development.

Patients are threatened with discontinuing therapy during the recovery phase for a variety of reasons, including the belief that they are already well or economic considerations. As a consequence, the treatment pattern must be recreated, incurring more expenditures and lengthening the duration of therapy (Riskesdas, 2018)

Regularity or adherence to therapy by patients with pulmonary tuberculosis is highly reliant on how patients with pulmonary tuberculosis behave throughout treatment and on the factors that influence behavior. Numerous variables may impact the efficacy of pulmonary tuberculosis therapy, most notably the duration of the 6- to 8-month treatment regimen. Failure of the treatment process as a result of the patient's disobedience of the instructions and rules for medication administration, which include the dose, method, time, and duration of administration, will result in the development of immunity to all drugs (Multiple Drug Resistance) and recurrence. According to interviews with health workers, attempts to manage pulmonary tuberculosis at the Lut Tawar Health Center have included a TB program and close surveillance by police if pulmonary tuberculosis patients are late in carrying medications to the Puskesmas (WHO, 2016). However, this monitoring has not been entirely effective since it is difficult for patients with pulmonary tuberculosis to adhere to normal therapy, which results in many patients dropping out (drop out of treatment).

\section{Methods}

The design of this research is Analytical with a Cross Sectional approach. It is a study to study the dynamics of the correlation between risk factors and effects, by approaching, observing or collecting data all at once. The population in this study were all TB patients who were treated 
at the Lut Tawar Health Center, Lut Tawar District, Central Aceh Regency, as many as 33 TB patients. The sample uses total sampling, the entire population.

\section{Results and Discussion}

Table 1. Characteristics of Respondents by Age at Lut Tawar Health Center, Lut Tawar District, Central Aceh Regency

\begin{tabular}{|c|c|c|c|}
\hline No. & Age of respondents & f & Percentage \\
\hline 1 & $<10$ years & 5 & 15 \\
\hline 2 & $11-20$ years & 20 & 61 \\
\hline 3 & $>20$ Years & 8 & 24 \\
\hline \multicolumn{2}{|c|}{ Total } & 33 & 100 \\
\hline
\end{tabular}

There are 5 respondents aged ten years or under (15 percent), 20 respondents aged eleven to twenty years (61 percent), and 8 respondents aged more than twenty years (75 percent) according to the study findings ( 24 percent $)$.

Table 2. Characteristics of Respondents by Gender at the Lut Tawar Health Center, Lut Tawar District, Central Aceh Regency.

\begin{tabular}{|c|c|c|c|}
\hline No. & Gender & f & Percentage \\
\hline 1 & Woman & 9 & 27 \\
\hline 2 & Man & 24 & 73 \\
\hline & Total & $\mathbf{3 3}$ & $\mathbf{1 0 0}$ \\
\hline
\end{tabular}

Based on the results of the research, it can be seen that the respondents with female sex are 9 people $(27 \%)$, respondents with male sex are 24 people $(73 \%)$.

\section{Univariate Analysis}

The analysis carried out analyzes each variable from the results of the study. The purpose of this analysis is to explain/describe the characteristics of each of the variables studied.

Table 3. Frequency Distribution of Respondents' Answers About Compliance with Taking Medicines at the Lut Tawar Health Center, Lut Tawar District, Central Aceh Regency.

\begin{tabular}{|c|c|c|c|}
\hline No & Drug Compliance & f & Percentage \\
\hline 1 & Obedient & 12 & 36,4 \\
2 & Disobedient & 21 & 63,5 \\
\hline Sum & & $\mathbf{3 3}$ & $\mathbf{1 0 0}$ \\
\hline
\end{tabular}

The results of research conducted on 33 respondents can be seen that respondents who adhere to taking medication are 12 people $(36.4 \%)$, respondents who do not comply are 21 people $(63.5 \%)$.

\section{Respondents' Answers About Education}

Table 4. Frequency Distribution of Respondents' Answers About Education at the Lut Tawar Health Center, Lut Tawar District, Central Aceh Regency.

\begin{tabular}{|c|c|c|c|}
\hline No & Education & f & Percentage \\
\hline 1 & Low & 12 & 36.4 \\
2 & Intermediate & 20 & 60.6 \\
3 & High & 1 & 3.0 \\
\hline Sum & & $\mathbf{3 3}$ & $\mathbf{1 0 0}$ \\
\hline
\end{tabular}


According to the findings of a survey done on 33 respondents, respondents with low levels of education account for 12 people (36.4 percent), respondents with secondary education account for 20 people (60.6 percent), and respondents with higher levels of education account for one person (3.0 percent).

\section{Respondents' Answers About Work}

Table 5. Distribution of Respondents Frequency by Occupational Category at the Lut Tawar Health Center, Lut Tawar District, Central Aceh Regency

\begin{tabular}{|c|c|c|c|}
\hline No & Work & f & Percentage \\
\hline 1 & Not Working & 16 & 48,5 \\
2 & Work & 17 & 51,5 \\
\hline \multicolumn{2}{|c|}{ Sum } & $\mathbf{3 3}$ & $\mathbf{1 0 0}$ \\
\hline
\end{tabular}

The results of research conducted on 33 respondents can be seen that respondents who do not work are 16 people (48.5), respondents who work are 17 people $(51.5 \%)$.

\section{Respondents' Answers About Distance from Residence}

Table 6. Frequency Distribution of Respondents Based on Distance of Residence at the Lut Tawar Health Center, Lut Tawar District, Central Aceh Regency

\begin{tabular}{|c|c|c|c|}
\hline No & Distance of Residence & f & Percentage \\
\hline 1 & Far & 18 & 54,5 \\
2 & Near & 15 & 45,5 \\
\hline \multicolumn{2}{|c|}{ Sum } & $\mathbf{3 3}$ & $\mathbf{1 0 0}$ \\
\hline
\end{tabular}

According to the findings of a survey done on 33 respondents, respondents who live at a distance from their place of employment account for 18 individuals (54.5 percent), while respondents who live near to their place of employment account for 15 people (45.5 percent ).

Table 7. Frequency Distribution of Respondents Based on Knowledge in Lut Tawar Health Center, Lut Tawar District, Central Aceh Regency

\begin{tabular}{|c|c|c|c|}
\hline No & Knowledge & f & Percentage \\
\hline 1 & Less & 1 & 3.0 \\
2 & Enough & 16 & 48,5 \\
3 & Good & 16 & 48,5 \\
\hline Sum & & $\mathbf{3 3}$ & $\mathbf{1 0 0}$ \\
\hline
\end{tabular}

According to the findings of a study done on 33 respondents, it can be noted that respondents with adequate knowledge include 16 individuals (48.5 percent) and respondents with strong knowledge comprise 16 people (48.5 percent) (48.5 percent ).

\section{Respondents' Answers About Drug Side Effects}

Table 8. Frequency Distribution of Respondents Based on Side Effects of Taking Drugs at the Lut Tawar Health Center, Lut Tawar District, Central Aceh Regency

\begin{tabular}{|c|c|c|c|}
\hline No & $\begin{array}{c}\text { Side effects of taking } \\
\text { medication }\end{array}$ & f & Percentage \\
\hline 1 & Heavy & 20 & 60,6 \\
2 & Keep & 11 & 33,3 \\
3 & Light & 2 & 6,1 \\
\hline \multicolumn{2}{r|}{ Sum } & $\mathbf{3 3}$ & $\mathbf{1 0 0}$ \\
\hline
\end{tabular}


According to the findings of the study, which included 33 participants, side effects of taking drugs in the heavy category were experienced by 20 people ( 60.6 percent), side effects of taking drugs in the moderate category were experienced by 11 people (33.3 percent), and side effects of taking drugs in the mild category were experienced by two people ( 2 percent) ( 6.1 percent).

Table 9. Frequency distribution of respondents by category of family support at the Lut Tawar Health Center, Lut Tawar District, Central Aceh Regency

\begin{tabular}{|c|c|c|c|}
\hline No & Family Support & f & Percentage \\
\hline 1 & Support & 22 & 66,7 \\
2 & Not supportive & 11 & 33,3 \\
\hline Sum & & $\mathbf{3 3}$ & $\mathbf{1 0 0}$ \\
\hline
\end{tabular}

The results of research conducted on 33 respondents can be seen that respondents who support are 22 people (66.7\%) and patients who do not support are 11 people $(33.3 \%)$.

\section{Bivariate Analysis}

\section{Education}

Table 10. Relationship between Education and Compliance with Medicines for Pulmonary Tuberculosis Patients at the Lut Tawar Health Center, Central Aceh Regency

\begin{tabular}{|c|c|c|c|c|c|c|c|c|}
\hline \multirow[t]{3}{*}{ No } & \multirow[t]{3}{*}{ Education } & \multicolumn{4}{|c|}{ Drug Compliance } & \multirow{2}{*}{\multicolumn{2}{|c|}{ Sum }} & \multirow{3}{*}{$\begin{array}{c}p \\
\text { (value) }\end{array}$} \\
\hline & & \multicolumn{2}{|c|}{ Disobedient } & \multicolumn{2}{|c|}{ Obedient } & & & \\
\hline & & $\mathbf{f}$ & $\%$ & f & $\%$ & f & $\%$ & \\
\hline 1 & Low & 12 & 100 & 0 & 0 & 12 & 100 & \multirow[t]{4}{*}{0,000} \\
\hline 2 & Intermediate & 0 & 0 & 20 & 100 & 20 & 100 & \\
\hline 3 & Tall & 0 & 0 & 1 & 100 & 1 & 100 & \\
\hline & Total & 12 & & 21 & & 33 & & \\
\hline
\end{tabular}

According to the data in the table above, 12 of the respondents who have limited knowledge on medication adherence fall into the group of those who are obedient. Medication adherence is in the obedient category for 0 people $(0$ percent) and from 20 respondents who have secondary education, namely 20 people (100 percent) and from 1 respondent who has higher education adherence to taking medication is in the obedient category, namely 1 person with higher education adherence to taking medication in the obedient category, namely 1 person with higher education (100 percent ). Because of these findings, we may conclude that the pvalue for the Person Chi-Square statistical test is equal to or less than 0.01 . This suggests that there is a link between education and compliance with taking medications for patients with pulmonary tuberculosis at the Lut Tawar Health Center in Central Aceh Regency, and that this association exists.

\section{Work}

Table 12. Employment Relationship with Compliance with Medicines for Pulmonary Tuberculosis Patients at Lut Tawar Health Center, Central Aceh Regency

\begin{tabular}{|c|c|c|c|c|c|c|c|c|}
\hline \multirow{3}{*}{ No } & \multirow{2}{*}{ Work } & \multicolumn{4}{|c|}{ Drug Compliance } & \multicolumn{2}{c|}{ Sum } & \multirow{2}{*}{$\begin{array}{c}\boldsymbol{p} \\
\text { (value) }\end{array}$} \\
\cline { 3 - 8 } & & Disobedient & \multicolumn{2}{|c|}{ Obedient } & \multicolumn{2}{|c|}{} \\
\cline { 3 - 8 } & & $\mathbf{f}$ & $\mathbf{\%}$ & $\mathbf{f}$ & $\mathbf{\%}$ & $\mathbf{f}$ & $\mathbf{\%}$ & \multirow{2}{*}{0,000} \\
\hline 1 & Not Working & 12 & 76 & 4 & 25 & 16 & 100 & \\
\hline 2 & Work & 0 & 0 & 17 & 100 & 17 & 100 & \\
\hline & Total & $\mathbf{1 2}$ & & $\mathbf{2 1}$ & & $\mathbf{3 3}$ & & \\
\hline
\end{tabular}


According to the data in the table above, 4 people ( 25 percent) out of the 16 respondents who did not work with medication adherence in the obedient category and 17 people ( 75 percent) out of the 17 respondents who worked with medication adherence in the obedient category did not work with medication adherence (100 percent ). A statistical test for continuity correction was performed, and the findings showed that the p-value was equal to or less than 0.01 . For pulmonary TB patients at the Lut Tawar Health Center in Central Aceh Regency, this suggests that there is a link between employment and adherence to medicine.

\section{Residence Distance}

Table 13. Relationship between residence distance and adherence to medication for pulmonary tuberculosis patients at the Lut Tawar Health Center, Central Aceh Regency

\begin{tabular}{|c|c|c|c|c|c|c|c|c|}
\hline \multirow[t]{3}{*}{ No } & \multirow{3}{*}{$\begin{array}{l}\text { Distance of } \\
\text { Residence }\end{array}$} & \multicolumn{4}{|c|}{ Drug Compliance } & \multirow{2}{*}{\multicolumn{2}{|c|}{ Sum }} & \multirow{3}{*}{$\begin{array}{c}p \\
\text { (value) }\end{array}$} \\
\hline & & \multicolumn{2}{|c|}{ Disobedient } & \multicolumn{2}{|c|}{ Obedient } & & & \\
\hline & & $\mathbf{f}$ & $\%$ & $\mathbf{f}$ & $\%$ & $\mathbf{f}$ & $\%$ & \\
\hline 1 & Far & 12 & 66,7 & 6 & 33,3 & 18 & 100 & \multirow[t]{3}{*}{0,000} \\
\hline \multirow[t]{2}{*}{2} & Near & 0 & 0 & 15 & 100 & 15 & 100 & \\
\hline & Total & 12 & & 21 & & 33 & & \\
\hline
\end{tabular}

According to the data in the table above, 6 people (33.3 percent) out of 18 respondents who live far away and have medication adherence in the obedient category, and 15 people out of 15 respondents who live close to each other and have medication adherence in the obedient category, are in the obedient category (100 percent ). A statistical test for continuity correction was performed, and the findings showed that the p-value was equal to or less than 0.01 . This means that for pulmonary TB patients at the Lut Tawar Health Center in Central Aceh Regency, there is a link between the distance between their homes and their adherence to medicine.

\section{Knowledge}

Table 14. Relationship between knowledge and adherence to medication for pulmonary tuberculosis patients at the Lut Tawar Health Center, Central Aceh Regency

\begin{tabular}{|c|c|c|c|c|c|c|c|c|}
\hline \multirow[t]{3}{*}{ No } & \multirow[t]{3}{*}{ Knowledge } & \multicolumn{4}{|c|}{ Drug Compliance } & \multirow{2}{*}{\multicolumn{2}{|c|}{ Sum }} & \multirow{3}{*}{$\begin{array}{c}p \\
\text { (value) }\end{array}$} \\
\hline & & \multicolumn{2}{|c|}{ Disobedient } & \multicolumn{2}{|c|}{ Obedient } & & & \\
\hline & & $\mathbf{f}$ & $\%$ & $\mathbf{f}$ & $\%$ & $\mathbf{f}$ & $\%$ & \\
\hline 1 & Less & 0 & 0 & 1 & 4 & 1 & 100 & 0,000 \\
\hline 2 & Enough & 12 & 75 & 4 & 25 & 16 & 100 & \\
\hline 3 & Good & 0 & 0 & 16 & 100 & 16 & 100 & \\
\hline & Total & 12 & & 21 & & 33 & & \\
\hline
\end{tabular}

In accordance with the data in the table above, it can be concluded that there was one respondent who possessed less knowledge of medication compliance in the obedient category, namely one person (4 percent), and there were four respondents who had sufficient knowledge of medication compliance in the obedient category, namely four respondents ( 25 percent), and there were sixteen respondents who had good knowledge of medication compliance in the obedient category (100 percent ). Because of these findings, we may conclude that the $p$-value for the Person Chi-Square statistical test is equal to or less than 0.01. To put it another way, at the Lut Tawar Health Center in Central Aceh Regency, there is a positive association between understanding and compliance with treatment regimens for patients with pulmonary TB. 


\section{Side Effects of Taking Drugs}

Table 15. The Relationship of Side Effects of Taking Drugs with Compliance with Taking Medicines of Pulmonary Tuberculosis Patients at the Lut Tawar Health Center, Central Aceh Regency

\begin{tabular}{|c|c|c|c|c|c|c|c|c|}
\hline \multirow[t]{3}{*}{ No } & \multirow{3}{*}{$\begin{array}{c}\text { Side Effects of } \\
\text { Taking } \\
\text { Medication }\end{array}$} & \multicolumn{4}{|c|}{ Drug Compliance } & \multirow{2}{*}{\multicolumn{2}{|c|}{ Sum }} & \multirow{3}{*}{$\begin{array}{c}p \\
\text { (value) }\end{array}$} \\
\hline & & \multicolumn{2}{|c|}{ Disobedient } & \multicolumn{2}{|c|}{ Obedient } & & & \\
\hline & & $\mathbf{f}$ & $\%$ & $\mathbf{f}$ & $\%$ & f & $\%$ & \\
\hline 1 & Heavy & 12 & 60 & 8 & 40 & 20 & 100 & 0,002 \\
\hline 2 & Keep & 0 & 0 & 11 & 100 & 11 & 100 & \\
\hline 3 & Light & 0 & 0 & 2 & 100 & 2 & 100 & \\
\hline & Total & 12 & & 21 & & 33 & & \\
\hline
\end{tabular}

It can be seen from the table above that out of 20 respondents who had side effects of taking medication in the severe category, 8 people ( 40 percent), out of the eleven who had side effects of taking medication in the moderate category with medication adherence (100 percent), and two who had side effects of taking medication in the mild category with the obedient category, 8 people (40 percent) (100 percent ). $\mathrm{P}$-value $=0.0020 .05$ is the result of a Person Chi-Square statistical test. There is a correlation between pharmaceutical side effects and treatment adherence among pulmonary TB patients at the Lut Tawar Health Center, Central Aceh Regency.

\section{Family support}

Table 16. Relationship between family support and adherence to medication for pulmonary tuberculosis patients at the Lut Tawar Health Center, Central Aceh Regency

\begin{tabular}{|c|c|c|c|c|c|c|c|c|}
\hline \multirow[t]{3}{*}{ No } & \multirow{3}{*}{$\begin{array}{c}\text { Family } \\
\text { Support }\end{array}$} & \multicolumn{4}{|c|}{ Drug Compliance } & \multirow{2}{*}{\multicolumn{2}{|c|}{ Sum }} & \multirow{3}{*}{$\begin{array}{c}p \\
\text { (value) }\end{array}$} \\
\hline & & \multicolumn{2}{|c|}{ Disobedient } & \multicolumn{2}{|c|}{ Obedient } & & & \\
\hline & & $\mathbf{f}$ & $\%$ & f & $\%$ & $\mathbf{f}$ & $\%$ & \\
\hline 1 & Unsupportive & 11 & 50 & 11 & 50 & 22 & 100 & 0,024 \\
\hline 2 & Support & 1 & 9,1 & 10 & 90,9 & 11 & 100 & \\
\hline & Total & 12 & & 21 & & 33 & & \\
\hline
\end{tabular}

More over half of those with family support who were obedient to their doctor's orders were found to be in the non-supportive group, whereas only half of those with family support who were obedient to their doctor's orders were found to be in the non-supportive category $(90,9$ percent). There is a correlation between family support and medication adherence for pulmonary TB patients at the Lut Tawar Health Center in Central Aceh Regency, according to the findings of the Fisher's Exact Test statistical study.

\section{Multivariate Analysis}

The relationship between education, work, knowledge, side effects of drugs and family support at the Lut Tawar Health Center, Central Aceh Regency

The relationship between education, occupation, knowledge, side effects of drugs and family support can be seen in the following table 
Table 17. Educational relationships, employment, knowledge, drug side effects and family support in Central Aceh Regency Lut Tawar Health Center

\begin{tabular}{|c|c|c|c|c|c|c|}
\hline \multirow[t]{2}{*}{ No } & \multirow[t]{2}{*}{ Variable } & \multirow[t]{2}{*}{ B } & \multirow[t]{2}{*}{ Itself. } & \multirow[t]{2}{*}{$\begin{array}{l}\operatorname{Exp} \\
(\mathbf{B})\end{array}$} & \multicolumn{2}{|c|}{$\begin{array}{c}\text { 95\% C.I.for } \\
\text { EXP(B) }\end{array}$} \\
\hline & & & & & Lower & Upper \\
\hline 1 & Education & 1,679 & 0,002 & 5,363 & 1,665 & 17,268 \\
\hline 2 & Work & 0,551 & 0,303 & 1,735 & ,608 & 4,950 \\
\hline 3 & Knowledge & 1,432 & 0,005 & 4,186 & 1,382 & 12,679 \\
\hline 4 & $\begin{array}{l}\text { Side effects of the } \\
\text { drug }\end{array}$ & 1,578 & 0,000 & 4,845 & 1,487 & 15,793 \\
\hline 5 & Family support & 1,509 & 0,002 & 4,045 & 1,227 & 9,793 \\
\hline & Constant & -4.294 & & & & \\
\hline
\end{tabular}

The results of the multivariate analysis in table 17 show that the education variable $(p=0.002)$, knowledge $(\mathrm{p}=0.005)$, side effects of drugs $(\mathrm{p}=0.000)$, was associated with medication adherence of pulmonary TB patients with $p$ value $<0.05$ while the work variable $(p=0.303)$ there was no correlation with medication adherence of pulmonary TB patients at the Lut Tawar Health Center, Central Aceh Regency with $\mathrm{p}$ value $>0.05$

Table 18. The relationship between education, knowledge, side effects of drugs and family support at the Lut Tawar Health Center, Central Aceh District

\begin{tabular}{|c|c|c|c|c|c|c|}
\hline \multirow[t]{2}{*}{ No } & \multirow[t]{2}{*}{ Variable } & \multirow[t]{2}{*}{ B } & \multirow[t]{2}{*}{ Itself. } & \multirow{2}{*}{$\begin{array}{r}\operatorname{Exp} \\
\text { (B) }\end{array}$} & \multicolumn{2}{|c|}{$\begin{array}{l}\text { 95\% C.I.for } \\
\text { EXP (B) }\end{array}$} \\
\hline & & & & & Lower & Upper \\
\hline 1 & Education & 1,743 & 0,004 & 5,715 & 1,785 & 18,301 \\
\hline 2 & Knowledge & 1,456 & 0,007 & 4,291 & 1,412 & 13,037 \\
\hline 3 & $\begin{array}{l}\text { Side effects of } \\
\text { the drug }\end{array}$ & 1,355 & 0,000 & 3,876 & 1,322 & 11,359 \\
\hline 4 & Family support & 1,355 & 0,014 & 3,876 & 1,322 & 11,359 \\
\hline & Constant & -4.289 & & & & \\
\hline
\end{tabular}

The results of the multivariate analysis in table 18 show that the variables of education, knowledge, side effects of drugs and family support are related to drug adherence of pulmonary TB patients and the variable side effects of drugs is the dominant variable associated with adherence to medication for pulmonary TB patients at the Lut Tawar Health Center. Central Aceh District

\section{Educational Relationship with Compliance with Drug Taking of Pulmonary Tuberculosis Patients in Puskesmas Lut Tawar Central Aceh Regency}

Education is the process of changing attitudes and behavior of a person or group of people in maturing humans through teaching and training efforts. Likewise, as stated by Notoatmodjo (2010) that education is directly related to one's knowledge, so it is assumed that the higher the level of education, it is expected that one's knowledge will increase.

Education is a planned effort so that individuals or communities can do what is taught by educational behavior. Someone who is highly educated when experiencing illness will increasingly need health service facilities as a place of treatment for himself and his family. The more individuals have higher education, the more they will realize that health is an important thing for life so they are motivated to make visits to better health care facilities. Based on research by Shulihah Absor, et al (2020) there is a relationship between education 
and medication adherence. The results of this study prove that the lower the level of education, the more people who do not comply with treatment (Zuliana, 2015).

According to the researcher's assumption that the higher the level of education, knowledge is also expected to increase. Respondents with upper secondary education are more obedient to taking medication because they have the knowledge that taking medication is good for healing pulmonary tuberculosis experienced by respondents. Because if it is not consumed, it will worsen the disease that has been experienced.

\section{Relationship between work and adherence to medication for pulmonary tuberculosis patients at the Lut Tawar Health Center, Central Aceh Regency}

Work should not be an obstacle for those who do not want to take medication, given the schedule for taking packaged drugs so that it does not interfere with their activities. The distribution of work for TB sufferers in the Lut Tawar Health Center area is housewives, entrepreneurs, farmers, fishermen and civil servants. So this data shows that most of the general work undertaken by the respondents is outside the room. The data of this study are not in accordance with the theory in curry (2010) which says that TB transmission will be faster in places with little air circulation (Salam, 2020).

According to the researcher's assumption, work has something to do with adherence to taking TB medication because patients who do not work are more busy with other activities so they often forget and even pass the time. Meanwhile, patients who work are more regular in taking medication because before leaving for work they start with breakfast and take medication regularly.

\section{Relationship between residence distance and adherence to medication for pulmonary tuberculosis patients at the Lut Tawar Health Center, Central Aceh Regency}

The distance from a tuberculosis patient's house is influenced by the availability of transportation access to the nearest service place. The results of this study are in line with research conducted by Nandang Tisna (2013) that the farther the distance from the head of the family's house to the place of health care, the less use of health services. Then in access to health facilities, it is possible for someone to use them (Yulisetyaningrum et al., 2019)

According to the researcher's assumption that distance of residence is related to medication adherence, what causes patient non-compliance in taking medication is the patient's assumption that treatment costs money, for patients who live far away must spend money for transportation or must meet other needs that must be considered rather than the importance treatment. Therefore, this must be straightened out because pulmonary TB treatment is now available free of charge, so that there is no reason for patients not to seek treatment.

\section{Relationship between Knowledge and Compliance with Medicines for Pulmonary Tuberculosis Patients at the Lut Tawar Health Center, Central Aceh Regency}

Non-adherence to taking medication is caused by ignorance about the importance of medication. This is influenced by the patient's knowledge which is still minimal about knowledge about the disease and treatment of tuberculosis. In addition, the ability to have a reaction from the drug that is consumed. Side effects of drugs such as itching, nausea, vomiting, bone pain and headaches can be triggers where the patient feels that his health condition is not improving, so that the patient is no longer obedient in swallowing his tuberculosis medication. Lusiane Adam's research (2020) found that there was a relationship between knowledge of pulmonary tuberculosis sufferers and adherence to taking anti-tuberculosis drugs in the working area of the East City Public Health Center. 
The researcher's assumption that there is a relationship between knowledge and adherence to medication cannot be separated from the patient's knowledge and support from the family as well as the patient's strong desire to recover. Most of the patients in this study already had good knowledge in terms of medication adherence. Things that are usually done and not usually done during treatment and side effects of drugs. Because with knowledge a person can obtain and improve his health status.

\section{The Relationship of Side Effects of Taking Drugs with Compliance with Taking Drugs in Pulmonary Tuberculosis Patients at the Lut Tawar Health Center, Central Aceh Regency}

The results showed that there were drugs suspected of causing side effects such as vomiting, namely Rifampicin and Isoniazid. Other side effects experienced by patients due to OAT (Anti Tuberculosis Drugs) are itching on the skin 60\%, balance disorders as much as $57.5 \%$, heartburn as much as 55\%, red urine 55\%, no appetite, hearing loss 50\%, joint pain, and tingling 45\% (Yulisetyaningrum et al., 2019).

The results of the study on the effects of this drug are supported by a similar study conducted by Caroll (2012) on 655 respondents. From this study, it was found that the main side effects that most often arise in TB patients are digestive disorders (53 people), joint muscle pain disorders (22 people), psychological disorders (10 people), visual disturbances ( 9 people) and visual disturbances. ( 9 people) and nervous disorders ( 8 people). These side effects are more common in patients undergoing second-line therapy, but the type of first-line drug that most often causes side effects is Pyrazinamide, generally occurring in more than 1 person out of 6 respondents. Isoniazid side effects occurred in 5 people ( 3 people with redness of the skin, 1 person with hepatitis and 1 person with nervous disorders). Ethambunol caused visual disturbances in 9 people. Pyrazinamide caused joint muscle pain in 22 people and digestive disorders in 2 people. There is a tendency that the milder the side effects felt by the respondents, the more obedient they will be in taking TB drugs and the more severe the side effects will have an impact on the respondent's non-adherence in taking TB drugs (Seniantara et al.. 2020).

According to the researcher's assumption, adherence to taking TB medication plays an important role in the healing process of pulmonary tuberculosis, because only by taking medication regularly and obediently will the patient recover completely. However, patients who do not comply are caused by the side effects of drugs that are caused, especially the drugs that are consumed for a long time so that patients feel the side effects caused by TB drugs actually cause other diseases. In the end decided not to take TB drugs regularly.

\section{Relationship between family support and adherence to medication for pulmonary tuberculosis patients at the Lut Tawar Health Center, Central Aceh Regency}

The role of the family also encourages patients to form actions to comply with the treatment being undertaken. Encouragement from the patient's family is needed so that the patient feels comfortable and feels valued even though he is experiencing an illness, so that the patient has the spirit to recover for the sake of the people around him (Muna et al., 2014).

Support provided for sick family members is to meet the needs of food and drink, and also bear the costs for treatment. If there is a problem faced by the sufferer, the family must provide advice for solving the problem. Support from the family makes the sufferer not feel burdened by the disease he suffers. This is due to the attention of his family, so the sufferer does not feel alone. Patient compliance is highly demanded in long-term treatment. From this compliance, it is hoped that the ability of bacteria in the body will decrease and die. If TB patients are not obedient in taking medication, it can cause low patient recovery rates, high mortality rates, and increased recurrences and more fatal is the occurrence of germ resistance to several antituberculosis drugs, so TB disease is very difficult to cure (Muna et al., 2014) 
According to the researcher's assumption, family support is very much needed in medication adherence. If the family does not support it, the patient feels unmotivated to recover so they are not obedient in taking the drug. In addition, family support can be given to patients by escorting patients when taking drugs at health care facilities and always providing positive support for healing the disease in patients with pulmonary TB.

\section{Relationship of Education, Knowledge, Side Effects of Drugs and Family Support at Lut Tawar Health Center, Central Aceh Regency}

The TB recovery period is different for each patient, this depends on the patient's health condition and the severity of the TB symptoms experienced. However, to ensure complete recovery, patients must undergo TB treatment for 6-9 months. The rules for taking TB medicine will be adjusted to the health condition and severity of the disease (Fauziyah, 2016)

Side effects of TB drugs can vary from one patient to another. Some side effects of OATs may be mild and go away on their own. However, it is not uncommon for patients to experience severe side effects (Ana, 2012)

The results showed that OAT causes side effects such as digestive tract disorders (nausea, vomiting, diarrhea), fever, hepatotoxicity, anemia, urine redness, neuropathy, hearing loss, visual disturbances, joint pain. According to the researcher's assumption, adherence to taking TB medication plays an important role in the healing process of pulmonary tuberculosis, because only by taking medication regularly and obediently will the patient recover completely. However, patients who do not comply are caused by the side effects of drugs that are caused, especially the drugs that are consumed for a long time so that patients feel the side effects caused by TB drugs actually cause other diseases. In the end decided not to take TB drugs regularly.

Morbidity and mortality due to tuberculosis is a very serious problem, especially due to the problem of side effects due to the use of Anti Tuberculosis Drugs (OAT). Discontinuation of therapy due to side effects caused germ resistance, thus increasing the burden of disease and the burden on the patient himself.

TB patients who do not comply with treatment are most likely due to long-term use of drugs, side effects that may arise, and lack of awareness of patients with their disease. To get the right treatment results, it is necessary to monitor the side effects of drugs. All TB patients who seek treatment should be informed about the side effects of anti-tuberculosis drugs. This is very important to do so that patients do not misunderstand which can lead to drug withdrawal. Most sufferers feel unable to tolerate the side effects of OAT experienced during treatment. The severity of the side effects experienced will have an impact on patient treatment adherence and may even result in loss of follow-up from treatment

\section{Conclusion}

The most influential research result is Education, which shows that the higher the education, the more obedient in treatment, and conversely, the lower the education level, the more disobedient in treatment. A person's level of education greatly influences his frame of mind. Someone who is highly educated generally has good knowledge and the greater his ability to absorb, receive or adopt information. The higher a person's education, the higher the level of understanding or adherence to a healthy lifestyle. It can be concluded that a person's low education greatly affects absorption in receiving information so that it can affect a person's level of understanding in this case regarding pulmonary TB, treatment methods and the impact of irregularities in taking tuberculosis drugs. 


\section{Suggestion}

It is recommended to the puskesmas or health workers who manage the TB treatment program to be able to provide support to patients and families so that they always control their family members' medication adherence so that drug withdrawal and resistance do not occur. Health workers must also provide health education related to information about TB disease and information about medication adherence. Health workers must also provide information about the effects of drugs so that they continue to take TB drugs until they recover. To get the right treatment results, it is necessary to monitor the side effects of drugs for all TB patients who seek treatment

\section{References}

Adam.L. (2020). Pengetahuan Penderita Tuberkulosis Terhadap Kepatuhan Minum Obat Anti Tuberkulosis. Jurnal Health And Sport Journal..2 (1).

Ana, S. (2012). Evaluasi Kepatuhan Penggunaan Obat Pada Pasien Tuberkulosis Rawat Jalan di Balai Besar Kesehatan Paru masyarakat Surakarta. Thesis. Fakultas Farmasi. Universitas Muhammadiyah Surakarta.

Fauziyah, U. (2016). Analisis Faktor yang Berhubungan dengan Kepatuhan Minum Obat Pasien TB Paru Berdasarkan 77 Health Belief Model di Wilayah KerjaPuskesmas Umbulsari Kabupaten Jember. management nursing standard. 25(47), page 48-56

Kemenkes (2017). Pedoman nasional pengendalian tuberkulosis. Jakarta: Kementrian Kesehatan Republik Indonesia.

Makhfudli, F. (2016). Faktor yang Mempengaruhi Konversi BTA Pada PasienTuberkulosis Paru dengan Strategi Dots Kategori 1 di Puskesmas Pegirian Kecamatan Semampir Kota Surabaya. Fakultas Kedokteran Universitas Airlangga. http://www.fk.unair.ac.id/scientific-papers. Pantai Aceh Barat Daya (Kajian di Puskesmas Blangpidie). J Respire Indo. 31(2)

Muna, L., \& Soleha, U. (2014). Motivasi Dan Dukungan Sosial Keluarga Mempengaruhi Kepatuhan Berobat Pada Pasien TB Paru Di Poli Paru Bp4 Pamekasan. Journal of Health Sciences, 7(2)

Notoatmodjo, S. (2010). Ilmu Perilaku Kesehatan. Jakarta: Rineka Cipta

Salam. Wahyuno. M. T. (2020). Pengaruh Jarak Ke Fasilitas Pelayanan Kesehatan Terhadap Kejadian Default Pada Penderita TB Paru di RSUD Goeteng Taroeenadibrata Purbalingga. MPPKI. 3 (3).

Seniantara. Kadek.I. Theresia.I. Adang. Gabrilianda.Y. (2020). Pengaruh Efek Samping OAT (Obat Anti Tuberculosis) Terhadap Kepatuhan Minum Obat Pada Pasien TBC Di Puskesmas. STIKes Suaka Insan Banjarmasin.

WHO (2017). Global Tuberculosis Report. Geneva: World Health Organization.

WHO (2018). WHO Treatment Guidelines for Drug Resistant Tuberculosis Update. Geneva: WHO Press.

Yulisetyaningrum. Hidayah. N. Yuliarti.R. (2019). Hubungan Jarak Rumah Dengan Kepatuhan Minum Obat Pada Pasien TBC Di RSI Sunan Kudus. Jurnal Ilmu Keperawatan Dan Kebidanan. 10 (1). 248-255

Zuliana, I. (2015). Pengaruh Karakteristik Individu, Faktor Pelayanan Kesehatandan Faktor Peran Pengawasan Minum Obat terhadap Tingkat Kepatuhan Penderita TB 
Paru dalam Pengobatan di Puskesmas Pekan Labuhan Kota Medan. Thesis. FKM: USU. 